\title{
British aerospace industry wants more government support
}

\begin{abstract}
London. Britain's aerospace manufacturers, hoping to persuade government officials of the need to support key technologies to counter growing US competition, have asked the Department of Trade and Industry (DTI) to back a national research programme in advanced civil aeronautics research. In particular, they want the DTI to increase its support for such research by a factor of four, from $£ 26$ million (US\$38 million) to $£ 100$ million a year.
\end{abstract}

The proposal, drawn up by an advisory group of industrialists and academics known as the DTI's aviation committee, was originally put to the department last November but has only just been made public. It argues that a "national strategic technology acquisition plan" is needed to provide a boost to the industry's own research efforts comparable to what US companies receive from the National Aeronautics and Space Administration (NASA), which spends about $\$ 900$ million a year in the field. Britain has historically provided substantial direct aid for civil aviation research, most recently for the development of Airbus, but that support has ended as the programme approaches commercial viability.

"We want a plan formulated jointly by government, industry, research establishments and the academic community, which will prevent us all going off in different directions", says John Stollery, professor of aeronautics at the Cranfield Institute of Technology and chairman of the committee. According to Stollery, there are many areas of aviation technology, ranging from aero-engines to advanced avionic systems, in which Britain is a world leader. "If we are to maintain this type of lead, we need realistic support similar to our competitors", he says.

So far, the DTI has shown little enthusiasm for the idea, and the budget for civilian aerospace research is scheduled to decline next year by 15 per cent, to $£ 22$ million. Aerospace officials, however, are hoping to change the government's mind by pointing to the new activist policies of President Bill Clinton and by citing evidence that the US government is spending considerably more than the three per cent of turnover accepted as a limit under a trade agreement signed with the European Commission last July.

Last year's expenditures by NASA of $\$ 902$ million barely exceeds three per cent of the US civil aviation industry's sales last year of $\$ 29$ billion. But Clinton has proposed that NASA spend an additional $\$ 550$ million over the next four years on civil aviation research, raising the government's level of support beyond the limit if, as seems likely, sales remain stagnant.
At present, the aeronautics and pharmaceutical industries make the largest positive contributions to Britain's balance of payments, capturing almost 12 per cent of the world's market for its products. But the committee warns that the industry's long-term future is threatened by a squeeze in defence spending and reduced civilian orders, and that its survival depends upon increased spending on long-term research.

Additional government spending is particularly important in such areas as advanced wing design, air traffic management systems and low-cost manufacturing. Aerospace officials say that support is growing for a national strategic plan in which increased government spending would be matched by the industry's own resources.

"Our message to the Treasury is that they have to look at public spending on research and development in aeronautics as an investment, not just an expenditure", says an official of the Society of British Aerospace Companies. "Our members feel that failure to sustain adequate $R \& D$ investment to counter international competition could mean an inevitable erosion of the UK's capability and once lost, the industry's leading position could not be regained."

David Dickson

\section{ESA is wary about impact of redesigned US station}

Munich. The European Space Agency (ESA), whose pressurized space module Columbus is an ECU2.4-billion (US\$3.1 billion) part of the \$30-billion US space station Freedom, is considering other alliances in the wake of yet another redesign of the US station and amid fears that the US Congress may reject even a smaller, cheaper version.

ESA's contribution to the US station has been withheld until concrete proposals emerge from the redesign ordered last month by US president Bill Clinton, who instructed the National Aeronautics and Space Administration (NASA) to scale down the station and cut its operational costs in half (see Nature 361, 195; 1993). The fortunes of manned space travel have had a rough ride in the past few years, with the United States finally joining Europe in questioning the costs of such programmes in times of recession. ESA abandoned its own plans for independent manned missions last year, after much internal strife, but its commitment to Columbus was reaffirmed last November despite a funding shortfall of 10 per cent.

ESA has already spent millions of dollars on Columbus, and it now seems likely that the redesign of Freedom will require a corresponding change in its space laboratory. But at least ESA will now have a voice. Europe and Japan were dismayed and angered last month by comments from the US government that ignored their significant roles in the programme (Japan is contributing a similar module). But since then NASA has promised to protect their interests (around 20 per cent of the programme's total cost), and both Europe and Japan are now represented in the discussions.

The deadline is very short. Clinton wants to see plans for the modified programme in early June, and a first draft is expected by mid-May. An outside advisory group, led by Charles Vest, president of the Massachusetts Institute of Technology, will provide a second layer of review.

In the meantime, ESA and its member countries are considering back-up plans for Columbus should the United States abandon Freedom completely. ESA acknowledges its disappointment that the programme is being redesigned "at a point when we were almost ready to cut iron with our contribution", according to a spokesman. "Redesigning our part will cost us more money." But Germany, which led the campaign to reduce spending on space to help pay for the soaring cost of reunification, sees the situation as an opportunity to reduce the cost of Columbus as well.

Germany's new minister for science and technology, Matthias Wissmann, thinks that another way to save money is to merge Russia's MIR 2 programme with NASA's Freedom. But experts say such a proposal would not be technically feasible.

It might, however, be possible to combine the Japanese and European modules. But such an alliance is unlikely given each country's desire to retain control over its own module. Despite the behind-thescenes politics, the most likely outcome of a redesigned Freedom is a slowing of ESA's programme to spread the costs over a longer period.

Alison Abbott 